\title{
Entrepreneurial Competence Self-Evaluation of Prospective Engineers in Food Science within the Context of Competitiveness
}

\author{
Sandra Iriste ${ }^{1}$ Dr.paed.; Irena Katane ${ }^{2}$ Dr.paed. \\ Latvia University of Life Sciences and Technologies, Latvia ${ }^{1,2}$ \\ sandra.iriste@gmail.com ${ }^{1}$; irena.katane@ inbox.lv²
}

\begin{abstract}
Ecological perspective creates the necessity to change the pedagogical approach in the study environment within the authentic context. The role of a higher education institution is: 1) to prepare specialists capable of continuous learning, to acquire the necessary knowledge independently, taking into account the rapid pace of technological advancement; 2) to educate prospective engineers in food science, to successful, competitive professional activity in the changing conditions of the modern labour market and professional environment of the industry, incl. to promote the formation and further development of their various competences. Entrepreneurial competence plays an important role in the competitiveness structure of any specialist. The aim of the study is to experimentally approbate the developed methodology for the entrepreneurial competence self-evaluation of prospective engineers in food science within the context of competitiveness development promotion. The TOP10 of self-evaluation indicators of entrepreneurial competence shows that: 1) students' group of study programme Food Quality and Innovation would readily to manage the company, dealing with human resource management; 2) while the students' group of study programme Food Science would prefer to do business by creating and investing in new food companies. The TOP10 list of indicators of the both experimental groups' participants has 5 indicators that coincide in both groups, depending on the sums of self-evaluation. The self-evaluation methodology of the entrepreneurial competence developed by the authors is valid and can be applied not only for the evaluation of prospective engineers in food science competitiveness, but also for its promotion.
\end{abstract}

Keywords: entrepreneurial competence, university education, competitiveness, ecological approach.

\section{Introduction}

On 24-25 May 2018 during the EHEA Ministerial Conference in Paris there was Paris Communiqué (Paris Communiqué..., 2018) adopted, where the demand for the services of higher education institutions, the growth of their specialists' careers and professional self-determination, their ability to be lifelong demanded, competitive in the labour market, to realize themselves as personalities and professionals, to be able to cooperate have become the criteria of competitive education, as well as the indicators of the level of a country's socio-economic development on the whole.

Independent and continuous lifelong learning, reflection competence and experience are an important precondition for an individual's viability under the changing environmental conditions (under the social, economic, professional activity environment and other types of environmental conditions) (Sustainable development goals..., 2015). Therefore, in the $21^{\text {st }}$ century there increases the topicality of the close connection between the concept of competitiveness and educational ecology, and the great significance of the developmental environment of competitiveness.

Ecological perspective creates the necessity to change the pedagogical approach in the study environment within the authentic context (Herrington, Oliver, 2000). The authentic study environment may be both physical and virtual; it should resemble the real world with all its opportunities, limits and complications (De Jong, 2015). Within the context of the promotion of the development of prospective engineers, the dual study environment of a higher education institution shall become the place for the new specialists' reflection and social activities, where there are discussions encouraged, people share with their amassed experienced and create new knowledge and experience, there is an on-going interaction between the study environment of a higher education institution and the environment of professional activities, where there are a number of changes in the professional activity of the modern engineer in food science, among which, in addition to production, entrepreneurship should be implemented. If the engineer is not doing business, he/she is just a tool (Fredholm et al., 2002). Thus, the role of a higher education institution is: 1) to prepare specialists capable of continuous learning, to acquire the necessary knowledge independently, taking into 
account the rapid pace of technological advancement; 2) to educate prospective engineers in food science, to successful, competitive professional activity in the changing conditions of the modern labour market and professional environment of the industry, incl. to promote the formation and further development of their various competences. Initially, the prospective specialist must be able to participate, but later must be able to manage all stages of the planning, design and production of processes, systems, objects and projects, as one of the most important task of modern education is to prepare any specialty, also engineers in food science, for an independent entrepreneurship: starting and running own business.

The environment of professional activities of food science engineers has many aspects; each aspect enables the prospective specialist to discover his or her creative potential, to self-develop and selforganize. This environment is related to both entrepreneurship - business, political and legal issues, the advanced technologies in food industry - and social environment - human resources management and society as a whole, paying particular attention to the needs and interests of consumers of services and goods produced in food science. Thus, the development of the prospective engineer in food science takes place in the transformative study process of the higher education institution, where the student develops not only as a spiritual, ecologically-minded personality, but also as a competitive specialist who is able to make appropriate and responsible decisions in competitive conditions of constantly changing environment. The environment of higher education institution also implies prospective engineers' internships - the environment of professional activities in the companies, where students interact with this multi-component environment, learn not only the join, becoming an integral part of this environment, but with their creative and innovative activity create and modify it. The new paradigm of competitiveness states that a competitive specialist is able to reconcile his/her own interests, needs and goals with the interests, needs and goals of the company in which he/she works, and with interests, needs and objectives of society as a whole, promoting sustainable development.

Thus, the ecological approach is one of the conceptual approaches on which the promotion of a competitive specialist development within environment of a higher education institution is based.

The competitiveness structure of any specialist, also engineer in food science, consists of several components, where entrepreneurial competence plays an important role. Entrepreneurial competence is one of the main issues of the contemporary research, as indicated by several recent publications (DuvalCouetil, Shartrand, Reed, 2016; Strauti, Dumitrache, Taucean, 2018).

The aim of the study is to experimentally approbate the developed methodology for the entrepreneurial competence self-evaluation of prospective engineers in food science within the context of competitiveness development promotion.

\section{Methodology}

In the first quarter of 2019 (January - March), at the Latvia University of Life Sciences and Technologies, at the Faculty of Food Technology a study was carried out in which authors developed methodology for the entrepreneurial competence self-evaluation of prospective engineers in food science was approbated.

The theoretical basis of the empirical study carried out became the results of previous theoretical studies in the following directions: competitiveness of prospective engineers (Katane, Baltusite, Katans, 2017; Llopis, Guerrero, 2018); ecological and constructivist approach in study environment (Briede, Pēks, 2014; Capra, 1996; Iriste, 2018; Liao, Wu, 2010; Young, 2016); competence of environment of professional activity (Delamare Le Deist, Winterton, 2005); business environment in the substantiation of the entrepreneurial competence (Boyatzis, 1982; Duval-Couetil, Shartrand, Reed, 2016; Komarkova et al., 2015; Liao, Wu, 2010; Liventsova, Rumyantseva, Syriamkina, 2016; Raven, 2001; Strauti, Dumitrache, Taucean, 2018; Verma, 2010).

Executive Director of International Organization VIF D. Young (Young, 2016) has highlighted the importance of the environment for the present and the future: to prospective engineers in food science could effectively participate in the changing, non-linear, unpredictable world of the 21 st century, they should understand the regularities of this new world, i.e. they will have to sell their product/service to the world, materials, also customers will come from all over the world, they will have to work in international companies, compete and collaborate with people from other countries, they will have to 
deal with global, complex, often unpredictable problems. The activity of prospective engineer in food science is influenced by the business environment in which the company operates. Knowing his/her environment of professional activities, the nature of the changes, responding skilfully to these changes, i.e., being able to adapt to them, failure can become a business success. Food production business environment is characterized by a continuous, rapid entry of new technologies, products and services into the market, it forces prospective specialists to constantly follow and try to understand which service/ product the consumer prefers and for which he/she is willing to pay for (Liao, $\mathrm{Wu}, 2010)$ because: 1) the development of information technology; 2) increase in international and local travel allow consumer to compare and strategically evaluate the relative costs and benefits of food products in the wider world, make the business environment even more transparent thus creating both opportunities and different risks in this environment (Verma, 2010). An engineer with entrepreneurial competence and entrepreneurial mindset will be better prepared for competitive action in a rapidly changing professional environment (Duval-Couetil, Shartrand, Reed, 2016). The prospective engineer should be ready to take the lead of his/her own business, based on the creation of creative projects, new technical samples, models and its implementation in the production. In other words, the entrepreneurial competence of a prospective specialist is his/her ability to turn ideas and opportunities into action (Komarkova et al., 2015; Strauti, Dumitrache, Taucean, 2018), his / her active life position manifestation, a willingness to address societal challenges by creating new products (Liventsova, Rumyantseva, Syriamkina, 2016). Thus, the willingness to start up and manage own business is linked not only to the knowledge and skills acquired during studies and the level of prospective specialist's entrepreneurial competence, but, first of all, to the motivation that, despite the various obstacles encountered during the achieving of the goal, allows the subject to maintain high level of activity. According to British psychologist J. Raven (Raven, 2001), the decisive factor in the expression of functional competences, incl. entrepreneurial competence is the motivation of the prospective specialist, its intensity to work in the particular field, i.e. the significance of the purpose for which the person works. The scientist puts motivation as a priority for personality. It is therefore essential nowadays to identify the factors that are the basis for the readiness to start and do own business, since the acquired knowledge, skills and competence in the entrepreneurship and management of the prospective engineers in food sciences do not yet guarantee their practical applicability in the future.

The methodology for the entrepreneurial competence self-evaluation of the prospective engineers in food science consisted of 32 indicators based on:

- the theoretical and empirical study carried out by the authors of the article, incl. studies on the competitiveness evaluation of prospective hospitality business managers, as well as reflection of experiences in the development and approbation of the competence of environment of professional activity self-evaluation methodology;

- Decision No. 88 (June 5, 2018) on the accredited study direction Production and Processing according to which the academic education bachelor (undergraduate) study programme Food Quality and Innovation of Latvia University of Life Sciences and Technologies, Faculty of Food Technology (according to the Academic Information Centre opinion, 13 June 2018) (Zinojums par..., 2018) - changes in the study programme have been approved, the title of the programme has been changed from Food Science to Food Quality and Innovation and academic education master (graduate) study programme Food Science is implemented. In accordance with the study plan of the study programme Food Quality and Innovation students acquire 6 study courses $(12 \mathrm{CP})$ in the field of entrepreneurship;

- Regulation of the Cabinet of Ministers No. 240 (May 16, 2014) on the State Academic Education Standard (Noteikumi par valsts..., 2014).

The eighteen students were invited to participate in the experiment: 1) the eight 4th year undergraduate students of the academic education study programme Food Quality and Innovation (engineering bachelor degree in Food Science), who formed experimental group A and 2) the ten $1^{\text {st }}$ year graduate students of the academic education study programme Food Science (engineering master degree in Food Science), who formed experimental group B. The reasons for selecting the study participants are as follows: $4^{\text {th }}$ year undergraduate students have already completed all the study courses in Economics and Management field intended for the study programme, while $1^{\text {st }}$ year graduate students have recently started their studies at the master programme, therefore their studies at master level could not have a significant impact on their level of entrepreneurial competence. 
Methods used in the study: 1) data obtaining methods: survey (questionnaires) of students (prospective engineers in food science), which comprised the system of indicators for entrepreneurial competence self-evaluation methodology developed by the authors; reflection of authors' experience; 2) data processing methods: primary data mathematical processing methods (for obtaining the descriptive statistics: Min, Max, A, Me, Mo, $\sum$ values); secondary data mathematical processing methods (for obtaining the conclusive statistics): Mann - Whitney U test, Kolmogorov-Smirnov Test SPSS 21.0 software.

In February 2019, the participants of the study completed the entrepreneurial competence of prospective engineers in food science self-evaluation questionnaire. The completion of the questionnaire took 20 minutes at the presence of the authors. Before completing the questionnaire, respondents were instructed how to do it, namely:

- the projective method: the line scale or the projective cut-off was used to determine the selfevaluation of the entrepreneurial competence; opposite statements are given at both ends of the line scale: I disagree and I agree;

- without long thinking, it should be noted with a cross-stripe of the cut-off to the extent that the student agrees or disagrees with the statement, purely intuitively evaluating his/her entrepreneurial competence within the given line.

In the second phase of the study, the collected data were processed; the results of the study were analysed, evaluated and interpreted.

\section{Results and Discussion}

Self-evaluation questionnaires received from students were collected, compiled and mathematically processed according to the group A and B participants (Table 1; Table 2), as well as to the 32 indicators of experimentally approbated methodology (Table 3; Table 4).

Table 1

\section{Results of the entrepreneurial competence self- evaluation of Group A participants: Descriptive} Statistics (n=8)

\begin{tabular}{|c|c|c|c|c|c|c|c|}
\hline \begin{tabular}{rr}
\multicolumn{2}{|}{ Indicators of Descriptive } \\
& Statistics \\
Students N & \\
\end{tabular} & Min & $\operatorname{Max}$ & $\mathbf{A}$ & Me & Mo & $\sum$ & $\begin{array}{l}\text { Proportion } \\
\text { Coefficient }\end{array}$ \\
\hline 1 & 1 & 7 & 6 & 3.5 & 4 & 105 & 0.33 \\
\hline 2 & 0 & 9 & 9 & 4 & $1 \mathrm{a} ; 5 \mathrm{~b}$ & 139 & 0.43 \\
\hline 3 & 2 & 10 & 8 & 5.5 & 4 & 173 & 0.54 \\
\hline 4 & 2 & 8 & 6 & 4.5 & 2 & 148 & 0.46 \\
\hline 5 & 1 & 8 & 7 & 4.5 & 5 & 138 & 0.43 \\
\hline 6 & 2 & 9 & 7 & 6 & 5 & 188 & 0.59 \\
\hline 7 & 2 & 6 & 4 & 4 & 3 & 130 & 0.41 \\
\hline 8 & 3 & 10 & 7 & 5 & 5 & 156 & 0.49 \\
\hline & & & & & Min & 105 & 0.33 \\
\hline & & & & & Max & 188 & 0.59 \\
\hline
\end{tabular}

The results of the descriptive statistics show that the minimum (Min) value of the group A proportion coefficient of entrepreneurial competence (Table 1) is 0.33, and the maximum (Max) value - 0.59. This means that the maximum value of the group A student with the highest self-evaluation proportion coefficient is only slightly above the possible average value of the coefficient $(0.59>0.50)$, which does not indicate a high self- evaluation. Minimum value of group B proportion coefficient of entrepreneurial competence is Min $=0.12$ (Table 2). This means that group B lowest student self-evaluation proportion coefficient is closer to 0 rather than 0.5 . Maximum value of group B proportion coefficient is $\operatorname{Max}=0.80$. This means that the student's highest proportion coefficient 0.80 is closer to 1 than 0.5 .

From the descriptive statistics it can be concluded that the $4^{\text {th }}$ year undergraduate students have lower amplitude in self-evaluation of entrepreneurial competence compared to $1^{\text {st }}$ year graduate students, which indicates the high amplitude of self-evaluation in the indicators of entrepreneurial competence in the graduate students' group. At the next stage of the descriptive statistics' analysis, the work with the indicators of the entrepreneurial competence was carried out. 
Table 2

Results of the Entrepreneurial Competence Self- Evaluation of Group B Participants: Descriptive Statistics $(\mathbf{n}=10)$

\begin{tabular}{|c|c|c|c|c|c|c|c|}
\hline \begin{tabular}{rr}
\multicolumn{2}{r}{ Indicators of Descriptive } \\
& Statistics \\
Students N &
\end{tabular} & Min & Max & $\mathbf{A}$ & Me & Mo & $\Sigma$ & $\begin{array}{l}\text { Proportion } \\
\text { Coefficient }\end{array}$ \\
\hline 1 & 3 & 8 & 5 & 5 & 5 & 174 & 0.54 \\
\hline 2 & 3 & 9 & 6 & 7 & $6 a ; 7 b$ & 218 & 0.68 \\
\hline 3 & 3 & 8 & 5 & 5 & 4 & 162 & 0.51 \\
\hline 4 & 0 & 10 & 10 & 9 & 10 & 249 & 0.78 \\
\hline 5 & 2 & 8 & 6 & 6 & 6 & 173 & 0.54 \\
\hline 6 & 0 & 10 & 10 & 3 & 3 & 106 & 0.33 \\
\hline 7 & 0 & 4 & 4 & 1 & 1 & 49 & 0.15 \\
\hline 8 & 0 & 3 & 3 & 1 & 1 & 37 & 0.12 \\
\hline 9 & 5 & 10 & 5 & 8 & 8 & 256 & 0.80 \\
\hline 10 & 4 & 9 & 5 & 6 & $5 a ; 7 b$ & 197 & 0.62 \\
\hline & & & & & Min & 37 & 0.12 \\
\hline & & & & & Max & 256 & 0.80 \\
\hline
\end{tabular}

The TOP10 of the entrepreneurial competence self-evaluation indicators was set up and analysed within group A (Table 3) and group B representative samples (Table 4). The sums of the TOP10 entrepreneurial competence self-evaluation indicators were ranked.

Table 3

10 Indicators of Entrepreneurial Competence with the Highest Self-Evaluation Sums in the Group A: Descriptive Statistics

\begin{tabular}{|c|l|c|c|}
\hline $\begin{array}{c}\text { Indicator } \\
\mathbf{N}\end{array}$ & \multicolumn{1}{|c|}{ Indicator formulations } & $\begin{array}{c}\text { Self- } \\
\text { evaluation } \\
\text { Sum } \Sigma\end{array}$ & $\mathbf{R}_{\Sigma}$ \\
\hline 6 & $\begin{array}{l}\text { Basic knowledge of business theory and practice with specialization in food } \\
\text { production }\end{array}$ & 55 & 1 \\
\hline 7 & Ability to link business with food production technology and science & 53 & 2 \\
\hline 2 & Knowledge of human resource management processes in the company & 50 & 3.5 \\
\hline 24 & Knowledge of costs and profit, its analysis & 50 & 3.5 \\
\hline 28 & $\begin{array}{l}\text { Ability to work independently with financial statements to determine the } \\
\text { actual situation and position of enterprise and give recommendations }\end{array}$ & 46 & 5 \\
\hline 1 & $\begin{array}{l}\text { Comprehensive knowledge of human resource management functions, } \\
\text { methods and trends }\end{array}$ & 45 & 6 \\
\hline 5 & $\begin{array}{l}\text { Ability to use the acquired theoretical foundations and skills, to take the } \\
\text { necessary actions in the management of human resources }\end{array}$ & 44 & 7.5 \\
\hline 26 & $\begin{array}{l}\text { Knowledge of analysing and evaluating performance of enterprise } \\
\text { Ability to define and provide solutions to human resources management } \\
\text { problems, to argue solutions and to identify the causes of problems }\end{array}$ & 44 & 7.5 \\
\hline 18 & $\begin{array}{l}\text { Knowledge of consumers motivation, market segmentation, marketing mix } \\
\text { interactions }\end{array}$ & 41 & 9.5 \\
\hline & \multicolumn{2}{|c|}{9.5} \\
\hline
\end{tabular}

Indicators that coincide with the first ten of group B

The highest ranking of TOP10 is held by the $6^{\text {th }}$ entrepreneurial competence indicator (Table 3 ), which shows the basic knowledge of $4^{\text {th }}$ year undergraduate students in business theory and practice with specialization in food production. Students also highly evaluated their ability to link entrepreneurship with food production technology and science. Several indicators $(2,1,5,4)$ indicate that group A respondents are able to successfully manage human resources.

Compared to group A students, only 2 human resource management indicators (Table 4) of group B were ranked in the TOP10 of entrepreneurial competence self-evaluation indicators, and ranked $4^{\text {th }}$ and $9^{\text {th }}$ respectively. In turn, in the group B students' representative sample high self-evaluation have 
indicators about knowledge on analysing and evaluating performance of enterprise, on its costs and profit, on latest food marketing trends and investment in production.

Table 4

10 Indicators of Entrepreneurial Competence with the Highest Self-Evaluation Sums in the Group B: Descriptive Statistics

\begin{tabular}{|c|l|c|c|}
\hline $\begin{array}{c}\text { Indicator } \\
\text { N }\end{array}$ & \multicolumn{1}{|c|}{ Indicator formulations } & $\begin{array}{c}\text { Self-evaluation } \\
\text { Sum } \sum\end{array}$ & R $\sum$ \\
\hline 24 & Knowledge of costs and profit, its analysis & 66 & 1 \\
\hline 19 & Knowledge of food marketing trends & 62 & 2 \\
\hline 25 & $\begin{array}{l}\text { Ability to evaluate the efficiency of investments and the use of } \\
\text { production resources }\end{array}$ & 3 \\
\hline 2 & Knowledge of human resource management processes in the company & 58 & 4 \\
\hline 7 & Ability to link business with food production technology and science & 57 & 5.5 \\
\hline 20 & Knowledge of product promotion principles in different markets & 57 & 5.5 \\
\hline 10 & $\begin{array}{l}\text { Knowledge of major economic scientific and practical principles and } \\
\text { regularities }\end{array}$ & 56 & 7.5 \\
\hline 26 & Knowledge of analysing and evaluating performance of enterprise & 56 & 7.5 \\
\hline 1 & $\begin{array}{l}\text { Comprehensive knowledge of human resource management functions, } \\
\text { methods and trends }\end{array}$ & 54 & 9 \\
\hline 8 & $\begin{array}{l}\text { Knowledge of basic theoretical principles and regularities at } \\
\text { microeconomic level }\end{array}$ & 53 & 10 \\
\hline
\end{tabular}

Indicators that coincide with the first ten of group A

The results of the study (Tables 3,4) show that, according to the rankings of the self-evaluation sums, there are 5 indicators of the TOP 10 that match in both groups only their ranks vary depending on the sum of self-evaluation. Tables 3 and 4 show that group A students are eager to manage a business, i.e. work with human resources in food companies, while group B students would prefer to do business, build and invest in new food businesses.

The ability to think critically, analyse and evaluate available information, use creatively their comprehensive knowledge of a particular situation in problem solving should be developed already in secondary education, based on the transdisciplinary approach and the constructivist approach that other researchers have pointed out in their research publications (Jurgena, Cēdere, Keviša, 2018).

\section{Results of conclusive statistics of the study conducted}

After analysis and evaluation of descriptive statistic, the authors of the article carried out secondary processing of the data in order to obtain conclusive statistics. Kolmogorov - Smirnov test was used for the determination of the correspondence to the normal distribution of the obtained values (Table 5) in the self-evaluation sums within group A and group B representative samples.

The results obtained lead to the conclusions that the empirical distribution of the self-evaluations of both groups corresponds to the normal distribution.

Table 5

Results of One=Sample Kolmogorov-Smirnov Test: Conclusive Statistics

\begin{tabular}{|c|c|c|}
\hline Groups & Kolmogorov-Smirnov Z & p-value \\
\hline A & 0.631 & 0.821 \\
\hline B & 0.362 & 0.999 \\
\hline
\end{tabular}

In the next stage of the data processing Mann - Whitney U test SPSS 21.0 (21.0) software was used for comparing sums of the entrepreneurial competence self-evaluation between group A and group B students.

Hypotheses of data secondary mathematical processing:

H0: self-evaluation of group A students = self-evaluation of group B.

H1: self-evaluation of group A students $\neq$ self-evaluation of group B.

The results of the conclusive statistics are summarised in Table 6 . 
Table 6

Results of Mann-Whitney U Test: Conclusive Statistics

\begin{tabular}{|c|c|c|c|c|c|}
\hline $\begin{array}{c}\text { Comparative } \\
\text { groups }\end{array}$ & $\begin{array}{c}\text { Number of students } \\
\text { (NS) }\end{array}$ & $\begin{array}{c}\text { Mean } \\
\text { Rank }\end{array}$ & $\begin{array}{c}\text { Sum of } \\
\text { Ranks }\end{array}$ & $\begin{array}{c}\text { Mann- } \\
\text { Whitney U }\end{array}$ & p-value \\
\hline A & 8 & 7.94 & 63.50 & \multirow{2}{*}{27.5} & \multirow{2}{*}{$\mathbf{0 . 2 6 6}$} \\
\hline B & 10 & 10.75 & 107.50 & \\
\hline
\end{tabular}

Since p-value $=0.266>\alpha=0.05$, the sums of entrepreneurial competence self-evaluation between group A and group B students do not differ significantly (there are no statistically significant differences). This means that there is no significant difference in the entrepreneurial competences proportion coefficients of the group A and group B students, although some differences between the results of the descriptive statistics of the two groups' self-evaluation were found.

\section{Conclusions}

- The results of the descriptive statistics analysis show that, according to the rankings of the selfevaluation sums, there are 5 indicators in the list of the TOP10 indicators that coincide in both groups - in the 4th year undergraduate students group of the academic education study programme Food Quality and Innovation and 1st year graduate students group of the academic education study programme Food Science, only their ranks vary depending on the sums of self-evaluation. The TOP10 of self-evaluation of entrepreneurial competence indicators shows that: 1) students' group of study programme Food Quality and Innovation would readily to manage the food company, dealing with human resource management; 2 ) while the students' group of study programme Food Science would prefer to do business by creating and investing in new food companies.

- The sums of entrepreneurial competence self-evaluation between undergraduate and graduate students group do not differ significantly since p-value $=0.266>\alpha=0.05$.

- As the entrepreneurial competence within competitiveness context is important for any industry specialist, including engineers in food science, the study carried out by the authors showed that decision of Latvia University of Life Sciences and Technologies, Faculty of Food Technology to make changes to the study programme Food Science (implemented until 12 June 2018), now Food Quality and Innovations, proved to be correct, namely, it was improved according to recommendations of Academic Information Centre experts and labour market requirements, increasing the amount of study courses in business from $4 \mathrm{CP}$ to $12 \mathrm{CP}$.

- The high amplitude of self-evaluation in the indicators of entrepreneurial competence in the $1 \mathrm{st}$ year graduate students of academic education study programme Food Science indicate the necessity to respect the differentiated approach in the process of promoting student entrepreneurial competence development in order to increase the prospective engineers competitiveness in the labour market.

- The self-evaluation methodology of the entrepreneurial competence developed by the authors is valid and can be applied not only for the evaluation of prospective engineers in food science competitiveness, but also for its promotion.

\section{Bibliography}

1. Boyatzis R.E. (1982). The Competent Manager: A Model for Effective Performance. New York: Wiley \& Sons.

2. Briede B., Pēks L. (2014). A constructivist approach in teaching in higher education for getting methodological and reflection competences. In V. Dislere (Ed.), The Proceedings of the International Scientific Conference Rural Environment. Education. Personality (REEP), 7. Jelgava: LLU, 84-89. Retrieved from https://llufb.llu.lv/conference/REEP/2014/Latvia-Univ-Agricult-REEP2014proceedings-84-89.pdf

3. Capra F. (1996). The web of life: A New Scientific Understanding of Living Systems. New York: Anchor Books.

4. De Jong F. (2015). The difference that makes the difference. Wageningen: Stoas Vilentum University of applied sciences and teacher education for vocational education.

5. Delamare Le Deist F.D., Winterton J. (2005). What is Competence? Human Resource Development International, 8(1), 27-46. doi: 10.1080/1367886042000338227 
6. Duval-Couetil N., Shartrand A., Reed T. (2016). The Role of Entrepreneurship Program Models and Experiential Activities on Engineering Student Outcomes. Advances in Engineering Education, 5(1), 1-27. Retrieved from https://advances.asee.org/wp-content/uploads/vol05/issue01/Papers/AEE-17-E-shipCouetil.pdf

7. Fredholm S., Krejcarek J., Krumholz S., Lindquist D., Munson S., Schiffman S., Bourne J. (2002). Designing an Engineering Entrepreneurship Curriculum for Olin College. In The Proceedings of the American Society of Engineering Education Annual Conference and Exhibition. Montreal: American Society of Engineering Education, 1-13. Retrieved from https://www.smunson.com/portfolio/projects/fredholmetalasee.pdf

8. Herrington J., Oliver R. (2000). An instructional design framework for authentic learning environments. Educational Research and Development, 48(3), 23-48. doi: 10.1007/BF02319856

9. Iriste S. (2018). Prospective Managers' of Hospitality Business Competitiveness Evaluation and Development promotion in the Dual Study Environment of Higher Education Institution. (Summary of Doctoral Thesis. Jelgava, LLU), 48-97. Retrieved from https://lufb.llu.lv/dissertationsummary/pedagogics/Sandra_Iriste_prom_darba_kopsavilkums2018_LLU_IMI.pdf

10. Jurgena I., Cēdere D., Keviša I. (2018). The Prospects of Transdisciplinary Approach to Promote Learners' Cognitive Interest in Natural Science for Sustainable Development. Journal of Teacher Education for Sustainability, 20(1), 5-19. doi: 10.2478/jtes-2018-0001

11. Katane I., Baltusite R., Katans E. (2017). Theoretical background for investigation and promotion of engineers competitiveness in education. In A. Aboltins (Ed.), The Proceedings of the International Scientific Conference Engineering for Rural Development, 16. Jelgava: LLU, 824-831. Retrieved from http://www.tf.llu.lv/conference/proceedings2017/Papers/N169.pdf

12. Komarkova I., Galiardi D., Conrads J., Collado A. (2015). Entrepreneurship competence: An Overview of Existing Concepts, Policies and Initiatives. Final Report of European Commission. Luxembourg: Publications Office of the European Union. Retrieved from http://publications.jrc.ec.europa.eu/repository/bitstream/JRC96531/jrc96531_final.pdf

13. Liao S.H., Wu C.C. (2010). System perspective of knowledge management, organizational learning and organizational innovation. Expert System with Applications, 37(2), 1096-1103. doi: 10.1016/j.eswa.2009.06.109

14. Liventsova E., Rumyantseva T., Syriamkina E. (2016). Development of Social and Entrepreneurial Skills of Students of Engineering and Technical Specialties in the Modern University. In VII Scientific Conference with International Participation Information-Measuring Equipment and Technologies, 79. Tomsk: National Research Tomsk State University, 1-9. doi: 10.1051/matecconf/20167901018

15. Llopis F., Guerrero F.G. (2018). Introducing competitiveness and industry involvement as learning tool. In The Proceeding of the IEEE Global Engineering Education Conference Emerging Trends and Challenges of Engineering Education. Tenerife: IEEE, 298-307. doi: 10.1109/EDUCON.2018.8363243

16. Noteikumi par valsts akadēmiskās izglītības standartu Nr. 240 [Regulations on the State Academic Education Standard N 240]. (2014). Retrieved from https://likumi.lv/ta/id/266187 (in Latvian)

17. Paris Communiqué, 2018. (2018). Communiqué of the Conference of European Ministers Responsible for Higher Education Empowering EHEA Paris 2018 Europe's Youth. Retrieved from http://www.ehea.info/Upload/document/ministerial_declarations/EHEAParis2018_Communique_final_952771.pdf

18. Raven J. (2001). The Conceptualisation of Competence. In J. Raven, J. Stephenson (Eds.), Competence in the Learning Society. New York: Peter Lang, 253-274. Retrieved from https://www.researchgate.net/publication/238793092_The_Conceptualisation_of_Competence

19. Strauti G., Dumitrache V.M., Taucean I.M. (2018). Entrepreneurial competences in economical engineering curriculum in Romania. Procedia - Social and Behavioral Sciences, 238, 737-742. doi: 10.1016/j.sbspro.2018.04.057

20. Sustainable development goals. 17 goals to transform our world. (2015). Retrieved from https://www.un.org/sustainabledevelopment/

21. Verma R. (2010). Choice Models and the Hospitality Business Environment. In C.A. Enz (Ed.), The Cornell School of Hotel Administration handbook of applied hospitality strategy. California: Thousand Oaks, 96-107. Retrieved from https://scholarship.sha.cornell.edu/articles/137/

22. Young D. (2016). What do Globally Competent Students Look Like? Retrieved from http://www.gettingsmart.com/2016/02/what-do-globally-competent-students-look-like/

23. Ziņojums par izmain,ām studiju programmā no 04.05.2018. [Report on changes in the study program from 04.05.2018.]. (2018). Dokumenti. Retrieved from http://svr.aic.lv/Forms/Programme.aspx?proi $\mathrm{d}=\mathrm{d} 4 \mathrm{a} 3 \mathrm{dbfc}-$ ceed-4615-a4ca-fb2594ed29ac (in Latvian) 